\title{
Coğrafi Bilgi Sistemleri Tabanlı Analitik Hiyerarşi Yöntemi Kullanılarak Ege Denizi'nde Rüzgâr ve Dalga Enerji Sistemleri İçin Yer Seçimi
}

\author{
Site Selection for the Wind and Wave Energy Systems in the \\ Aegean Sea Using GIS-based Analytical Hierarchy Process \\ İzlem Aydıner ${ }^{1}\left(\right.$, Derya Öztürk ${ }^{2 *}$
}

1,2 Ondokuz Mayıs Üniversitesi, Mühendislik Fakültesi, Harita Mühendisliği Bölümü, Samsun, TÜRKIYE Sorumlu Yazar / Corresponding Author*: dozturk@omu.edu.tr

\section{Öz}

Denizlerde entegre rüzgâr ve dalga enerji sistemleri, son yıllarda dünyada önemli araştırma konuları arasında yer almaktadır. Bu enerji sistemlerinden en verimli șekilde yararlanabilmek için kuruluma en uygun alanların belirlenmesi oldukça önemlidir. Bu çalışmada Ege Denizi'nde entegre rüzgâr ve dalga enerji sistemleri için uygun alanlar Coğrafi Bilgi Sistemleri (CBS) tabanlı Analitik Hiyerarşi Yöntemi (AHY) ile belirlenmiştir. Yer seçim kriterleri olarak; rüzgâr hızı, belirgin dalga yüksekliği, deniz derinliği, trafo merkezlerine uzaklık, limanlara uzaklık, kıyıya uzaklık ve deniz tabanı çökel tipleri seçilmiştir. Veriler CBS ortamında işlenmiş, kriter ağırlıklarının belirlenmesinde ve kriterlerin alt kategorilerinin/gruplandırılmış seçeneklerinin puanlandırılmasında ikili karşılaştırma yöntemi kullanılmıştır. Çalışmanın sonucunda, Ege Denizi'nde toplam 50,4 km² alanın entegre rüzgâr ve dalga enerji sistemlerinin kurulabileceği uygun alanlar olduğu ve bu değerin 43,4 $\mathrm{km}^{2}$ 'sinin Bozcaada çevresinde yer aldığı tespit edilmiştir. Çalışmanın sonuçları; CBS tabanlı AHY'nin denizlerde rüzgâr ve dalga enerji sistemleri için yer seçimi problemlerinde etkin bir şekilde kullanılabileceğini göstermiştir.

Anahtar Kelimeler: Coğrafi Bilgi Sistemi, Analitik Hiyerarşi Yöntemi, Yer Seçimi, Rüzgâr Enerjisi, Dalga Enerjisi

\section{Abstract}

Integrated wind and wave energy systems in the seas are among the important research topics in the world in recent years. It is crucial to determine suitable areas to make the most efficient use of these energy systems. In this study, the suitable areas for integrated wind and wave energy systems in the Aegean Sea were determined using Geographic Information Systems (GIS) based Analytical Hierarchy Process (AHP). Site selection criteria were determined as wind speed, significant wave height, seawater depth, distance to the transformer stations, distance to ports, distance to shorelines, and seabed sediment types. The data were processed in the GIS environment and the pairwise comparison technique was used to determine the criteria weights and to score the subcategories/grouped options of the criteria. As a result of the study, it was determined that a total area of 50,4 $\mathrm{km}^{2}$ in the Aegean Sea is suitable for the integrated wind and wave energy systems, and $43,4 \mathrm{~km}^{2}$ of this value is located in Bozcaada Island. The results of the study reveal that GIS-based AHP can be used effectively in site selection problems for wind and wave energy systems in the seas. 


\section{Giriş}

Dünyada artan nüfusla birlikte ortaya çlkan fazla enerji ihtiyacı sonucunda fosil yakıtların tükenme sorununa karşı bir çözüm olan, dünyanın her yerinde bulunan, sürdürülebilir ve en önemlisi çevreyi kirletmeyen yenilenebilir enerjilerin kullanımı dünyada giderek artmaya başlamıștır [1]. Başlıca yenilenebilir enerjiler; güneş enerjisi, rüzgâr enerjisi, dalga enerjisi, gelgit enerjisi, hidroelektrik enerji, jeotermal enerji ve biyokütle enerjisidir [2].

Yenilenebilir enerji kaynaklarının özellikleri ve enerji sistem teknolojileri birbirinden farklılık gösterir. Farklı avantajları, dezavantajları ve risklerinin olması her teknoloji için ayrı bir araştırma ve değerlendirme yapılmasını gerektirmektedir. Ayrıca yenilenebilir kaynaklardan hangi enerji kaynağının tercih edilmesi gerektiği de oldukça önemli bir konudur. Bir bölgede değerlendirme yapılırken yenilenebilir enerji kaynağının potansiyeli ve ne kadar verimli kullanılabileceği dikkate alınmalıdır. Bununla birlikte, yenilenebilir enerji sistemleri için kurulum ve ișletme gereksinimlerinin neler olduğu, altyapı maliyetleri, sistemin ekonomik olması, doğal kaynaklara ve çevreye verebileceği zararlar gibi tüm etmenler dikkate alınmalıdır. Bu şekilde çevresel ve ekonomik sorunlar en az düzeye düşürülebilmektedir [1].

Rüzgâr enerjisi, ekonomik kurulumu ve birçok alanda kurulabilmesinin mümkün olması ile diğer yenilenebilir enerji teknolojileri arasında en fazla tercih edilenidir [2]. Rüzgâr türbinlerinde yaşanan gelişim süresince rüzgâr santrallerinin çoğu karada kurulmuştur [3, 4]. Ancak yeryüzünün yaklașı \% \%0'ini kaplayan denizler önemli enerji kaynaklarından biridir [5]. Denizlerde daha yüksek rüzgâr potansiyeli olmasından dolayı 1970'lerin başlarında tasarlanmaya başlanan ve 1990'larda ilk kurulumunun yapılması ile küçük çaplı projeler ile başlayan deniz üstü rüzgâr türbinleri hızla gelişme göstermiş ve deniz üstü rüzgâr türbinlerinin kurulumu da giderek artmıştır [3, 6]. Deniz üstü rüzgâr santrallerinin kara üstü rüzgâr santrallerine göre avantajları; denizde rüzgâr hızının daha yüksek ve sürekli olması, oldukça büyük olan modern rüzgâr türbinlerinin taşınmasının karaya oranla daha kolay olması, karada kurulu rüzgâr türbinlerinin oluşturduğu gürültü sorununun ortadan kalkması ve karaya oranla daha geniş alanlara kurulabilir olması olarak sıralanabilir $[3,4]$.

Denizlerde rüzgâr enerjisiyle birlikte, rüzgârların etkisi ile oluşan dalgalar da yüksek bir enerji potansiyeline sahiptir [5]. Rüzgâr ve dalga arasindaki sinerjiden faydalanmak üzere iki ayrı sistemin birleştirilmesi ile yenilenebilir enerji potansiyelinin büyük bir kısmını oluşturan rüzgâr ve dalga enerjisinden daha iyi yararlanma fikri son yıllarda önem kazanmıs ve bu konuda önemli adımlar atılmaya başlanmıştır [7, 8]. Entegre rüzgâr ve dalga enerji sistemleri, deniz üstü rüzgâr türbinleri ve dalga enerjisi dönüştürücüleri arasındaki birleştirilme durumuna göre; ortak alana yerleștirilmiş sistemler, hibrit sistemler ve ada sistemleri olmak üzere üç sınıfta incelenebilmektedir [9]. Ortak alana yerleștirilmiş sistemlerde, mevcut ve uyumlu olan iki farklı sistem ayrı bir șekilde aynı alana yerleștirilmekte ve birbirlerine yakınlıklarından dolayı avantaj sağlanabilmektedir $[9,10]$. Hibrit sistemler, deniz üstü rüzgâr türbini ile dalga enerjisi dönüştürücüsünün aynı yapı üzerinde tasarlandığı, aynı altyapının ve temelin paylaşıldığı sabit ya da yüzer sistemlerdir [911]. Ada sistemleri, ikiden fazla denizel enerji sisteminin sabit ya da yüzer yapay adaların üstüne yerleștirilmesi fikrine dayanmaktadır [9]. Entegre rüzgâr ve dalga enerji sistemleri, yeni bir teknoloji olup üzerinde çalışmalar devam etmektedir [7, 12].

Denizlerde rüzgâr ve dalga enerji sistemlerinin birleştirilmesiyle aynı alan ortak kullanılarak denizel alanların daha doğru ve verimli kullanımı sağlanır, çevre üzerindeki olumsuz etkiler ve kurulum maliyeti azaltılır ve aynı alandan elde edilebilecek enerji miktarı arttırılır $[2,10]$. Ayrıca günlük ve mevsimlik olarak değişim gösterebilen yenilenebilir enerji kaynakları için iki sistemin bir arada kullanılması ile yedek bir güç oluşturulmaktadır [13].

Her ne kadar deniz kaynaklı enerjilerin potansiyelleri fazla olsa da sistem kurulumunun yapılması denizin özellikleri ile ilişkili olduğundan kurulum için uygun alanların belirlenmesi dikkatli bir değerlendirme gerektirmektedir $[1,5,14]$. Değerlendirme 
yapılırken yenilenebilir enerji kaynaklar potansiyelinin bölgelere göre değișiklik gösterebileceği dikkate alınmalıdır. Örneğin; rüzgâr tükenmeyen kaynaklardan biri olmasına rağmen bazı bölgelerde kullanımı verimli olmazken bazı bölgelerde daha yüksek potansiyele sahip olabilmektedir [2] Birleştirilmiş bir rüzgâr ve dalga enerji sistemi için en uygun ortak yerin belirlenmesi, hem rüzgâr hem de dalga enerjisi açısından değerlenme yapmayı gerektirmektedir [9].

Günümüzde ekonomi enerji ile bağımlı bir hale gelmişken, enerjinin kullanılabilirliği, konum ve uygun alanların belirlenmesine bağlı olmaktadır. Ayrıca politika, teknoloji ve coğrafyanın ilişkili olduğu bu gibi karmaşık durumlarda verilen bir kararın olası etkileri mutlaka dikkate alınmalıdır [15-17]. Yenilenebilir enerjiler için yer seçimi; teknik, ekonomik, çevresel ve sosyal açıdan değerlendirilme yapılması gereken mekânsal bir karar problemidir [18].

Mekânsal karar problemlerinde, birçok faktörün kararı etkilemesi nedeniyle problemler doğası gereği çok kriterlidir. Bu nedenle mekânsal verilerin toplanması, depolanması, işlenmesi ve analizi için güçlü bir araç olan Coğrafi Bilgi Sistemleri (CBS), Çok Kriterli Karar Analizi (ÇKKA) yöntemleriyle entegre edilerek mekânsal karar problemleri etkin bir șekilde çözülebilmektedir $[18,19]$. Mekânsal bir karar probleminde her bir kriterin katman olarak hazırlanabilmesi ve kriter katmanlarının karşılaştırılabilir hale getirilebilmesi, mekânsal verilerin saklanabilmesi, değișen durumlara göre güncellenebilme imkanı sağlayabilmesi ve üretilen analiz sonuçlarının gerek sayısal gerekse harita olarak görselleștirilebilmesi yönleri ile CBS tabanlı ÇKKA güçlü bir karar destek aracı olarak kullanılabilmektedir [20].

Literatürde çok sayıda ÇKKA yöntemi, mekânsal karar problemlerinin çözümü için CBS ile entegre edilmiștir. $\mathrm{Bu}$ yöntemlerden özellikle Analitik Hiyerarşi Yöntemi (AHY) geniş bir kullanım alanı bulmuştur. AHY, karar vermeye yardımcı üç özelliğe sahiptir. AHY'de öncelikle bir amaç ve alt seviyelerden oluşan bir hiyerarşi kurularak karmaşık problem ayrıștırılmaktadır. İkinci olarak, kriterler arasında ikili karşılaştırmalar yapılarak kriterlerin sonuç üzerindeki etkilerine göre değerlendirme yapılması sağlanmaktadır. Son olarak ise yapılan işlem ve değerlendirmelerin tutarlılığının kontrolü sağlanabilmektedir. AHY karar problemindeki karmaşıklı̆̆ın giderilmesi ve tutarlılık analizi ile karar problemleri için önemli bir araç haline gelmiștir [17].

Son yıllarda dünyada önemli araștırma konuları arasında yer alan entegre rüzgâr ve dalga enerji sistemleri, uzun vadeli enerji strateji ve politikalarının önemli bir bileșeni olarak değerlendirilmektedir. Ülkemiz konumu gereği yenilenebilir enerji kaynakları potansiyeli ve çeşitliliği yönünden oldukça avantajlıdır. Karada kurulu rüzgâr santralleri ile elektrik enerjisi üretimi gelișme göstermiștir ancak üç tarafı denizlerle çevrili olan ve boğazlara sahip olan ülkemiz için dalga, deniz üstü rüzgâr enerjileri ve boğaz akıntıları gibi deniz kaynaklı enerjilerden faydalanma imkânı olmasına rağmen henüz böyle bir sistem kurulumu gerçekleşmemiştir [21, 22].

Bu çalışma kapsamında Ege Denizi'nde entegre rüzgâr ve dalga enerji sistemlerinin kurulumu için uygun yerler, CBS tabanlı AHY kullanılarak tespit edilmiştir. Analizde kullanılan kriterler ve kısıtlar; teknolojik, ekonomik ve çevresel açıdan değerlendirme yapılarak belirlenmiştir. Kriter ağırlıkları ve kriterlerin alt kategorileri/ gruplandırılmış seçenekleri ikili karşılaştırma yöntemi ile belirlenmiştir. Analizler sonucunda Ege denizi entegre rüzgâr ve dalga enerji sistemlerinin kurulumu açısından beş uygunluk seviyesine sınıflandırılmıștır.

\section{2. Çalışma Alanı: Ege Denizi}

Çalışmada; rüzgâr hızının fazla olması, üretilen enerjinin tüketilecek enerji bölgelerine yakın olması, kıyı şehirlerinin nüfusunun fazla olması ve küçük çaplı enerji projeleri için de uygun olan adaların bulunması nedeniyle Ege Denizi incelenmiştir (Şekil 1).

Balkan ve Anadolu Yarımadaları arasında Akdeniz'e bağlı bir deniz olan Ege Denizi, kuzeyde Marmara Denizi ile Karadeniz'den ayrılmakta ve yine Boğazlar yolu ile Karadeniz'e bağlanmaktadır. Denizin kuzey sınırlarını karalar oluștururken, güney sınırlarını Mora Yarımadası'ndan başlayıp Anadolu'ya kadar devam eden ve bir yay şeklinde sıralanmış, Yunanistan'a bağlı Çuha, Küçük Çuha, Girit, Çoban, Kerpe ve Rodos adaları olușturmakta ve Akdeniz'den ayrılmaktadır $[23,24]$. 


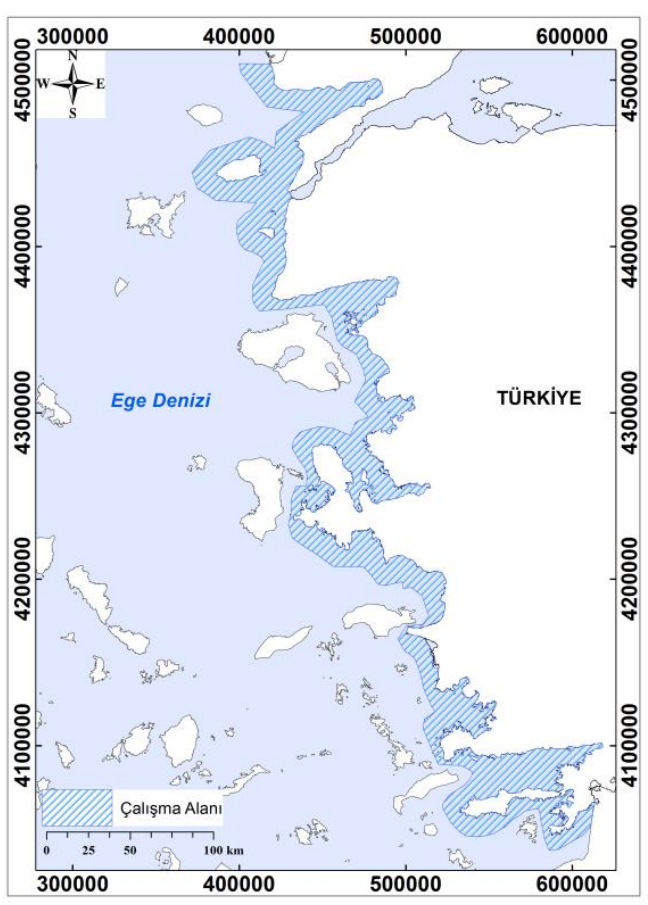

Şekil 1. Çalışma alanı

Coğrafi konumu, kıyılarının girintili çıkıntılı yapısı, irili ufaklı çok sayıda adaları, koyları, bes büyük körfezi, yarımadaları ve boğazlar ile olan bağlantısı, Ege Denizi'ne farklı bir özellik katmaktadır [23, 25]. Aynı zamanda ülkemizde denizlerin kıyı uzunluklarına bakıldığında, 2805 km ile en uzun kıyı uzunluğuna sahip deniz Ege Denizi'dir [26]. Ege Denizi'nin kuzeyinden güneyine Edirne, Çanakkale, Balıkesir, İzmir, Aydın ve Muğla illerinin kıyıları bulunmaktadır [24]. Ege Bölgesi karaları ve adalarına bakıldığında Akdeniz iklimine sahip olduğu görülmektedir [27]. Ege Denizi ve kıyı bölgeleri; turizm, ulașım, yerleșim, sanayi ve balıkçllık gibi farklı sektörler için yoğun bir şekilde kullanılmaktadır [24]. Ancak Ege Denizi için çözülememiş bazı sorunlar bulunmaktadır. Uluslararası hukuka göre ülkelerin deniz alanlarının yakın ya da karşılıklı olma durumlarında anlaşma ile denizleri ayıracak belirleyici bir sınır oluşturulmalıdır. Türkiye ve Yunanistan'ın Ege Denizi'ndeki konumları da böyle bir sınır oluşturulmasını gerektirmesine rağmen Türkiye ve Yunanistan arasındaki deniz sınırı henüz bir anlaşmayla belirlenmemiștir. $\mathrm{Bu}$ durum deniz kullanım alanlarını da kısıtlamaktadır. Şu anda, Türkiye ve Yunanistan karasularının Ege Denizi'ndeki genişliği 6 deniz milidir [28]. Buna göre çalıșma alanı sınırları 6 deniz miline uygun olarak olușturulmuştur (Şekil 1).

\section{Materyal ve Yöntem}

Ege Denizi'nde entegre rüzgâr ve dalga enerji sistemleri için uygun yerlerin belirlenmesinde CBS tabanlı AHY kullanılmıştır. AHY, Thomas Saaty tarafından 1980'lerde geliştirilmiştir [15]. AHY; (1) hiyerarşinin oluşturulması, (2) üstünlüklerin belirlenmesi ve (3) mantıksal ve sayısal tutarlılığın sağlanması olmak üzere üç temel prensip üzerine kurulmuştur [29]. AHY'de temel düşünce, karmaşık ve yapılandırılmamış problemlerin, hiyerarşik bir yapıda, en üst seviyeden problemin çözüleceği seviyeye kadar yapılandırılmasıdır. En az üç seviyeden oluşan hiyerarşik yapının en üst seviyesinde ana amaç ve amacın alt seviyelerinde ise sirasiyla kriterler ve seçenekler bulunmaktadır [16]. Mekânsal veriler için seçenekler vektör veri yapısında nokta, çizgi ve poligonlarla; raster veri yapısında piksellerle ifade edilir. AHY'de kriter ağırlıkları ikili karşılaştırma yöntemi ile belirlenir. Ayrıca karar probleminin özelliğine göre, bir kriter için seçeneklerin değerlerini elde etmek amacıyla da ikili karşıllaştırma yöntemi kullanılabilir. Ancak özellikle raster verilere dayalı mekânsal karar analizlerinde çok fazla sayıda seçenek söz konusu olduğundan birçok mekânsal karar analizinde bu durum gerçekleştirilemez. Bu durumda her kriter için alt kategoriler veya gruplandırılmış seçenekler oluşturularak ikili karşılaştırmaların yapılması söz konusudur [30]. Kriter ağırlıkları ve her kriter için seçenek değerleri kullanılarak, her seçenek için AHY sonuç analiz değeri Eşitlik (1)'de belirtilen şekilde hesaplanır [20].

$A_{A H Y}=\sum_{j}^{n} a_{i j} w_{j}$

Burada; $w_{j}, j$. kriterin ikili karşılaştırma yöntemi ile belirlenen ağırlığı, $a_{i j}$, j. kriter için $i$. seçeneğin değeridir. Burada kriter ağırlıklarının toplam 1 olacak şekilde ve tüm kriter katmanlarının aynı değer aralığında standart değerlere sahip olacak şekilde düzenlemiş olması gereklidir [30].

Çalışmanın ilk adımında, CBS ortamında çalışma alanı sınırları olușturulmuş, analiz dışı bırakılacak alanlar belirlenerek çalışma alanından çıkarılmıștır. Rüzgâr ve dalga enerji 
sistemleri için yer seçiminde etkili olabilecek kriterler ve kriterlerin alt kategorileri/gruplandırılmış seçenekler de belirlenerek karar hiyerarşisi oluşturulmuştur. Daha sonra kriterlerin ağırlıkları ve kriterlerin alt kategori/gruplandırılmış seçenek değerleri ikili karşılaştırmalar kullanılarak hesaplanmıştır. Ardından, kriterlerin bir arada işleme girip değerlendirilebilmesi için tüm kriter katmanları için alt kategorilerin/gruplandırılmış seçeneklerin normalleștirilmiş değerleri hesaplanmıştır. $\mathrm{Bu}$ değerler kullanılarak CBS ortamında normalleştirilmiş kriter katmanları hazırlanmıștır. Son olarak kriter ağırlıkları ve normalleștirilmiș kriter katmanları kullanılarak AHY ile sonuç analiz katmanı oluşturulmuştur. AHY ile karar analizi sonucunda elde edilen uygunluk haritası beș seviyeye ayrılmıştır. Çalışmanın ana işlem adımlarını gösteren iş akış şeması Şekil 2'de gösterilmektedir. Verilerin düzenlemesi ve tüm analizler ArcGIS 10.0 yazılımı kullanılarak gerçekleştirilmiştir.

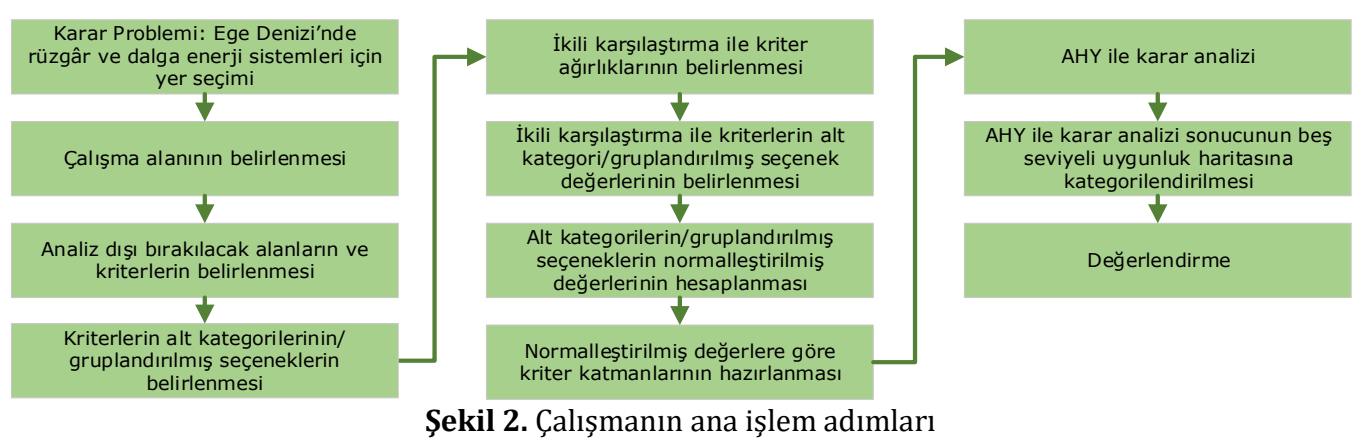

\subsection{Kriterlerin ve analiz dışı bırakılacak alanların belirlenmesi}

Ege Denizi'nde rüzgâr ve dalga enerji sistemleri için uygun yer seçiminde kullanılacak kriterler ve analiz dıșında bırakılacak alanlar, literatür araştırmaları [31-42], mevzuat, teknolojik, ekonomik ve çevresel kısıtlamalar ve verilerin mevcudiyeti doğrultusunda belirlenmiștir. Kriterler; (1) rüzgâr hızı, (2) belirgin dalga yüksekliği, (3) deniz derinliği, (4) trafo merkezlerine uzaklık, (5) kıyıya uzaklık, (6) limanlara uzaklık ve (7) deniz tabanı çökel tipi olarak belirlenmiștir. Rüzgâr ve dalga enerji sistemleri için kullanılması uygun olmayan ve bu nedenle analiz dışında bırakılacak alanlar; koruma alanları, kuş göç yolları ve çevresindeki $3 \mathrm{~km}$ 'lik tampon bölge, denizaltı telekomünikasyon kabloları ve çevresindeki 500 m'lik tampon bölge olarak belirlenmiştir. Yenilenebilir enerji projeleri her ne kadar çevre dostu olarak kabul edilse de bazı çevresel etkileri mevcut olduğundan koruma alanları ve kuş göç yollarının çevresinde oluşturulan tampon bölgeler analize dâhil edilmemiștir. Enerji sistemlerinin kurulumu ya da bakımı sırasında kaza tehlikesi olușturmaması açısından denizaltı telekomünikasyon kablolarının çevresinde oluşturulan tampon bölgeler de analiz dişında bırakılmıștır. Ayrıca literatür araştırmaları $[33,35,39,43]$ ve derin denizlerde sistem kurulumuyla ilgili teknolojik ve mali kısitlamalar çerçevesinde 50 m'den daha derin alanlar değerlendirme dıșında tutulmuştur. Benzer şekilde literatür araştırmaları [33, 40, 44] doğrultusunda rüzgâr hızının $6,5 \mathrm{~m} / \mathrm{s}^{\prime}$ den düşük olduğu yerler değerlendirmeye alınmamıştır.

Rüzgâr hızı ve belirgin dalga yüksekliği, rüzgâr ve dalga enerji sistemlerinin kurulum ve devamlılığı için ana kriterlerdir [45, 46]. Rüzgâr ve dalga enerji potansiyeli yüksek olan alanlarda enerji üretimi de daha fazla olmaktadır [46].

Deniz derinliği, rüzgâr ve dalga enerji sistemlerinin kurulum yerlerinin belirlenmesinde önemli bir değerlendirme kriteri ve tekno-ekonomik olarak kısıtlayıcı bir faktördür. Deniz derinliği arttıkça sistemin kurulumunun yapılması, işletim süresi içerisinde gereken bakım işlemleri, elektrik altyapısının hazırlanması ve demirleme işlemleri açısından projenin maliyeti artmaktadır. $\mathrm{Bu}$ nedenle proje maliyetinin azaltılması amacıyla genellikle derinliğin az 
olması tercih edilmektedir. Ayrıca projeye teknik kısıtlama getirmesinden dolayı belirli bir derinlik sınırı içinde değerlendirme yapılabilmektedir. Bu kısıtlar nedeniyle enerji açısından yüksek potansiyel içerebilecek deniz alanlarının kullanımı kısıtlanmaktadır [39, 4749].

Trafo merkezlerine uzaklık, kurulum maliyetini etkileyen önemli bir kriterdir. Deniz üstünde kurulu bir sistemde üretilen elektrik, kablolar ile karaya taşınıp uygun bir trafo merkezi ile bağlantı sağlanarak kullanılabilmektedir [39]. Rüzgâr ve dalga enerji sistemlerinin trafo merkezlerine yakınlığı iletim maliyetini düşüreceğinden, yer seçiminde trafo merkezlerine olan mesafenin kısa olması tercih edilmektedir [49].

Kıyıya uzaklık, kurulum ve bakım maliyetini etkileyen önemli bir kriterdir. Sistemin karaya bağlanacak elektrik altyapısı için gerekli olan kabloların uzunluğu arttıkça maliyeti de artmaktadır. Aynı zamanda bakım işlemleri için gerekli ekip ve malzemenin sağlanma maliyeti de artmaktadır. Bu durum, deniz üzerinde kurulu enerji sistemlerinin kıyıa olan uzaklığını maliyet üzerinde etkili bir kriter haline getirmektedir [48].

Limanlara uzaklık, enerji sistemlerinin kurulum ve bakım maliyetleri üzerinde etkili bir kriterdir. Hem kurulum aşamasında hem de ișletim süresi boyunca limanlardan yararlanılmaktadır. Bu nedenle rüzgâr ve dalga enerji sistemlerinin limanlara yakın mesafede olması tercih edilmektedir [47].

Deniz tabanı çökel tipleri, denizaltı kablolarının döşenmesi ile ilgili olarak maliyeti etkileyen bir kriterdir. Deniz tabanı çökel tipi eğer kum ve siltlere kiyasla daha sert ise maliyetin artmasına neden olabilmektedir. $\mathrm{Bu}$ nedenle genel olarak çökel tiplerinden çakıl da nispeten kabul edilebilir olmasına karşın özellikle kaya olduğunda kablo döșeme maliyetleri önemli ölçüde artmaktadır $[47,50]$.

Analiz dıșı bırakılacak alanlar ve kriter katmanlarının hazırlanması ve analizi için kullanılan veriler Tablo 1'de gösterilmiștir.

Tablo 1. Çalıșmada kullanılan veriler

\begin{tabular}{ll}
\hline Veri & Kaynak \\
\hline Kuş göç yolları & Tarım ve Köyişleri Bakanlığı (Kapatılan) \\
Koruma alanları & Yenilenebilir Enerji Genel Müdürlüğü \\
Denizaltı telekomünikasyon kabloları & Avrupa Deniz Gözetim ve Veri Ağı (EMODnet) \\
Rüzgâr hızı & Avrupa Orta Menzilli Hava Tahminleri Merkezi (ECMWF); Global Wind Atlas \\
Belirgin dalga yüksekliği & MetOcean Solutions \\
Deniz derinliği & Avrupa Deniz Gözetim ve Veri Ağı (EMODnet) \\
Trafo merkezleri & Yenilenebilir Enerji Genel Müdürlüğü \\
Limanlar & Ulaştırma ve Altyapı Bakanlı̆̆ı, Marine Traffic gemi veri tabanı \\
Kıyı çizgisi & Çevre ve Şehircilik Bakanlığı \\
Deniz tabanı çökel tipleri & Avrupa Deniz Gözetim ve Veri Ağı (EMODnet) \\
\hline
\end{tabular}

\subsection{Kriter ağırlıklarının belirlenmesi}

Rüzgâr ve dalga enerji sistemleri için uygun yer seçiminde kullanılacak kriterlerin ağırlıkları literatür araştırmaları $[31,37,40,41]$ doğrultusunda belirlenmiştir. Kriter ağırlıklarının hesaplanmasında ikili karșılaștırma yöntemi kullanılmıștır. İkili karşılaştırmaların gerçekleștirilmesinde Tablo 2'de yer alan bağıl önem ölçeği kullanılmıştır. Kriterlerin birbirlerine göre önemleri, amaca olan etkilerine göre sözel olarak belirlenmiş ve 1-9 aralığındaki sayı değerleri ile değerlendirmesi yapılarak ikili karşılaştırma matrisi oluşturulmuştur. Kriterlerin ikili karşılaștırmaları Tablo 3'te gösterilmektedir. İkili karşılaştırma matrisinde, her sütunun toplam değeri hesaplanmıs ve her eleman kendi sütun toplamına bölünmüștür. Son olarak her satırın ortalaması alınmıș ve bağıl ağırlıklar hesaplanmıștır (Tablo 4). 
DEÜ FMD 23(67), 217-232, 2021

Tablo 2. Bağıl önem ölçeği [51]

\begin{tabular}{cl}
\hline Önem Derecesi & Tanım (1. öge 2. ögeye göre) \\
\hline $\mathbf{1}$ & Eşit önemli \\
3 & Eşit önem ile biraz daha önemli arasında \\
4 & Biraz daha önemli \\
$\mathbf{5}$ & Biraz daha önemli ile fazla önemli arasında \\
6 & Fazla önemli \\
7 & Fazla önemli ile çok fazla önemli arasında \\
$\mathbf{8}$ & Çok fazla önemli \\
9 & Çok fazla önemli ile son derece önemli arasında \\
\hline
\end{tabular}

Tablo 3. Kriterlerin ikili karșılaștırmaları

\begin{tabular}{|c|c|c|c|c|c|c|c|}
\hline Kriter & K1 & K2 & K3 & K4 & K5 & K6 & K7 \\
\hline K1 & 1 & 1 & 3 & 5 & 7 & 8 & 9 \\
\hline K2 & 1 & 1 & 3 & 5 & 7 & 8 & 9 \\
\hline K3 & $1 / 3$ & $1 / 3$ & 1 & 3 & 5 & 6 & 7 \\
\hline K4 & $1 / 5$ & $1 / 5$ & $1 / 3$ & 1 & 3 & 4 & 5 \\
\hline K5 & $1 / 7$ & $1 / 7$ & $1 / 5$ & $1 / 3$ & 1 & 2 & 3 \\
\hline K6 & $1 / 8$ & $1 / 8$ & $1 / 6$ & $1 / 4$ & $1 / 2$ & 1 & 2 \\
\hline K7 & $1 / 9$ & $1 / 9$ & $1 / 7$ & $1 / 5$ & $1 / 3$ & $1 / 2$ & 1 \\
\hline \multicolumn{4}{|c|}{$\begin{array}{l}\text { K1: Rüzgâr hızı } \\
\text { K2: Belirgin dalga yüksekliği } \\
\text { K3: Deniz derinliği } \\
\text { K4: Trafo merkezlerine uzaklık }\end{array}$} & \multicolumn{3}{|c|}{$\begin{array}{l}\text { K5: Limanlara uzaklık } \\
\text { K6: Kıyıya uzaklık } \\
\text { K7: Deniz tabanı çökel tipi }\end{array}$} & \\
\hline
\end{tabular}

Tablo 4. Kriterlerin ağırlık hesabı

\begin{tabular}{lcccccccc}
\hline Kriter & K1 & K2 & K3 & K4 & K5 & K6 & K7 & Ağırlık \\
\hline K1 & 0,343 & 0,343 & 0,382 & 0,338 & 0,294 & 0,271 & 0,250 & 0,317 \\
K2 & 0,343 & 0,343 & 0,382 & 0,338 & 0,294 & 0,271 & 0,250 & 0,317 \\
K3 & 0,115 & 0,115 & 0,128 & 0,203 & 0,209 & 0,203 & 0,194 & 0,167 \\
K4 & 0,069 & 0,069 & 0,043 & 0,068 & 0,126 & 0,136 & 0,139 & 0,093 \\
K5 & 0,049 & 0,049 & 0,026 & 0,022 & 0,042 & 0,068 & 0,083 & 0,048 \\
K6 & 0,043 & 0,043 & 0,021 & 0,017 & 0,021 & 0,034 & 0,056 & 0,034 \\
K7 & 0,038 & 0,038 & 0,018 & 0,014 & 0,014 & 0,017 & 0,028 & 0,024 \\
\hline Toplam & 1,000 & 1,000 & 1,000 & 1,000 & 1,000 & 1,000 & 1,000 & 1,000 \\
\hline
\end{tabular}

Kriter ağırlıklarının hesaplanmasının ardından ikili karşılaştırmaların tutarlılığının belirlenmesi için tutarlılık oranı hesabı yapılmıştır. Tutarlılık oranı hesabında ilk olarak hesaplanan kriter ağırlıkları ile kriterlerin ikili karşılaștırmaları ile oluşturulmuş ikili karşılaştırma matrisi çarpılmıştır. Ardından, çarpım sonucu elde edilen değerler, ağırlık değerlerine bölünmüștür. Hesaplanan değerlerin ortalaması alınmış ve tutarlılık vektörünün $\lambda$ ortalama değeri hesaplanmıştır. Daha sonra tutarlılık indeksi (Tí), Eşitlik (2)'ye göre hesaplanmıştır. Eşitlik (3)'te gösterildiği şekilde tutarlılık indeksinin karşılaştırılan kriter sayısına $(n)$ bağlı olarak değișen tesadüfilik göstergesine $(T G)$ (Tablo 5) bölünmesiyle tutarlılık oranı (TO) elde edilmiştir. $\mathrm{Bu}$ çalışmada, değerlendirilen kriter sayısı 7 olduğundan dolayı Tablo 5'e göre tesadüfilik göstergesi 1,32'dir. Tutarlılık oranı için Thomas Saaty tarafından önerilen üst limit 0,10 olup, değer 0,10'un altında ise değerlendirmelerin yeterli bir tutarlılık gösterdiği kabul edilmektedir [29]. Eğer tutarlılık oranı 0,10'un üstünde ise ikili karşılaştırmaların yeniden gözden geçirilmesi gerekmektedir. $\mathrm{Bu}$ çalışmada kriter ağırlıklarının hesabı için gerçekleştirilen ikili karşılaştırmaların tutarlılık oranı 0,04 olarak hesaplanmıștır (Tablo 6). Bu değer, 0,10'un altında olduğu için değerlendirmeler tutarlıdır.

$$
\begin{aligned}
& T \dot{I}=\frac{\lambda-n}{n-1} \\
& T O=\frac{T \dot{I}}{T G}
\end{aligned}
$$


Tablo 5. Tesadüfilik göstergesi [20]

\begin{tabular}{cccccccccccccccc}
\hline $\boldsymbol{n}$ & $\mathbf{1}$ & $\mathbf{2}$ & $\mathbf{3}$ & $\mathbf{4}$ & $\mathbf{5}$ & $\mathbf{6}$ & $\mathbf{7}$ & $\mathbf{8}$ & $\mathbf{9}$ & $\mathbf{1 0}$ & $\mathbf{1 1}$ & $\mathbf{1 2}$ & $\mathbf{1 3}$ & $\mathbf{1 4}$ & $\mathbf{1 5}$ \\
\hline $\boldsymbol{T G}$ & 0,00 & 0,00 & 0,58 & 0,90 & 1,12 & 1,24 & 1,32 & 1,41 & 1,45 & 1,49 & 1,51 & 1,48 & 1,56 & 1,57 & 1,59 \\
\hline
\end{tabular}

Tablo 6. Tutarlılık oranı hesabı

\begin{tabular}{lc}
\hline Kriter ağırlıkları ile ikili karşılaștırma matrisinin çarpılıp toplanması & $\begin{array}{c}\text { Toplamların } \\
\text { ağırlıklara } \\
\text { bölünmesi }\end{array}$ \\
\hline$(0,317 \times 1)+(0,317 \times 1)+(0,167 \times 3)+(0,093 \times 5)+(0,048 \times 7)+(0,034 \times 8)+(0,024 \times 9)=2,424$ & 7,647 \\
$(0,317 \times 1)+(0,317 \times 1)+(0,167 \times 3)+(0,093 \times 5)+(0,048 \times 7)+(0,034 \times 8)+(0,024 \times 9)=2,424$ & 7,647 \\
$(0,317 \times 1 / 3)+(0,317 \times 1 / 3)+(0,167 \times 1)+(0,093 \times 3)+(0,048 \times 5)+(0,034 \times 6)+(0,024 \times 7)=1,269$ & 7,599 \\
$(0,317 \times 1 / 5)+(0,317 \times 1 / 5)+(0,167 \times 1 / 3)+(0,093 \times 1)+(0,048 \times 3)+(0,034 \times 4)+(0,024 \times 5)=0,675$ & 7,258 \\
$(0,317 \times 1 / 7)+(0,317 \times 1 / 7)+(0,167 \times 1 / 5)+(0,093 \times 1 / 3)+(0,048 \times 1)+(0,034 \times 2)+(0,024 \times 3)=0,343$ & 7,146 \\
$(0,317 \times 1 / 8)+(0,317 \times 1 / 8)+(0,167 \times 1 / 6)+(0,093 \times 1 / 4)+(0,048 \times 1 / 2)+(0,034 \times 1)+(0,024 \times 2)=0,236$ & 6,941 \\
$(0,317 \times 1 / 9)+(0,317 \times 1 / 9)+(0,167 \times 1 / 7)+(0,093 \times 1 / 5)+(0,048 \times 1 / 3)+(0,034 \times 1 / 2)+(0,024 \times 1)=0,170$ & 7,083 \\
\hline$\lambda=7,332$ & $T I=0,055$ \\
\hline
\end{tabular}

\subsection{Kriter katmanlarının hazırlanması}

Kriter katmanları UTM projeksiyonu WGS84 datumunda (Zone 35N) koordinatlandırılmıștır. Tüm katmanlar, çalıșma alanının büyüklüğü ve orijinal veri ölçekleri göz önünde bulundurularak $250 \mathrm{~m}$ piksel boyutlu raster veriler şeklinde düzenlenmiştir. Kriter katmanları Ege Denizi karasuları sınırları çerçevesinde kesilmiș ve rüzgâr ve dalga enerji sistemleri için kullanılması uygun olmayan alanlar maskelenerek analiz dışında bırakılmıştır.

Kriterlerin alt kategori/gruplandırılmıș seçenek değerlendirmelerinde ikili karşılaştırma yöntemi kullanılmıștır. Değerlendirmeler literatür araştırmaları [31, 37, 40, 41] ışığında gerçekleștirilmiştir. Deniz tabanı çökel tipleri katmanı dişındaki diğer katmanlar sayısal değerler taşımaktadır. Sayısal değerlere sahip rüzgâr hızı, belirgin dalga yüksekliği, deniz derinliği, trafo merkezlerine uzaklık, limanlara uzaklık ve kıyıya uzaklık katmanları, belirli sayı aralıklarına gruplandırılarak temsil edilmiştir. Gruplandırılmış seçenek değerlendirmelerinde rüzgâr hızı ve dalga yükseklikleri kriterlerinde değerin yüksek olması; deniz derinliği, trafo merkezlerine uzaklık, limanlara uzaklık ve kıyıya uzaklık kriterlerinde değerin düşük olması durumu, uygunluk açısından daha yüksek değerler almıştır. Deniz tabanı çökel tipi katmanı için ise alt kategoriler kum, çamurlu kum, kumlu çamur, çamur, karışık çökel ve kaba çökel olarak belirlenmiştir. Deniz üstü enerji sistemlerinin kurulumunda maliyeti düşürdüğü için genel olarak kumlu alanlara daha yüksek değerler verilirken, sert deniz dibi alanlarına daha düşük değerler ve çamurlu ve karışık çökel tipindeki yerlere ise orta değerler verilmektedir.

Kriterlerin alt kategori/gruplandırılmış seçenek değerlendirmelerinde ikili karşılaştırma yöntemi kullanıldığından her katmanın alt kategori/gruplandırılmış seçenek değerlerinin toplamı 1'dir. Ancak katmanların alt kategori/gruplandırılmış seçenek sayıları eşit olmadığından normalleştirme işlemi uygulanarak tüm kriterler ortak bir analize dâhil edilmeye uygun hale getirilmiștir. Normalleştirme işleminde Eşitlik (4)'te belirtilen en büyük değere göre doğrusal ölçek dönüşümü yaklaşımı [52] kullanılmıştır. Normalleștirme, en fazla öneme sahip olan ögenin ağırlığı 1 olacak şekilde gerçekleștirilmiştir.

$x_{i j}^{\prime}=\frac{x_{i j}}{x j^{\text {maks }}}$

Burada; $x_{i j}^{\prime} \quad i$. seçeneğin $j$. ölçüt için normalleștirilmiş değeridir. Normalleştirilmiş değerler 0-1 aralığında yer alır.

Kriterlerin alt kategori değerlendirmeleri için, ikili karşılaștırma sonucunda belirlenen değerler, tutarlılık oranları ve normalleştirilmiş değerler Tablo 7'de verilmektedir. Tutarlılık oranı tüm kriterler için 0,10'un altında hesaplanmıș olduğundan, tüm ikili karşılaștırmalar tutarlıdır. 
DEÜ FMD 23(67), 217-232, 2021

Tablo 7. İkili karşılaştırmalar ile elde edilen kriterlerin alt kategori/gruplandırılmış seçenek değerleri, tutarlılık oranları ve normalleștirilmiș değerler

\begin{tabular}{|c|c|c|c|}
\hline Kriterler & $\begin{array}{c}\text { Alt Kategoriler/ } \\
\text { Gruplandırılmış } \\
\text { Seçenekler }\end{array}$ & $\begin{array}{c}\text { İkili Karşılaştırma } \\
\text { Sonucunda Belirlenen } \\
\text { Değerler }\end{array}$ & $\begin{array}{c}\text { Normalleştirilmiş } \\
\text { Değerler }\end{array}$ \\
\hline \multicolumn{4}{|c|}{ Rüzgâr Hızı (m/s) } \\
\hline \multirow[t]{3}{*}{$(\mathrm{TO}=0,03)$} & $8,0-9,0$ & 0,633 & 1,000 \\
\hline & $7,0-8,0$ & 0,261 & 0,412 \\
\hline & $6,5-7,0$ & 0,106 & 0,167 \\
\hline \multicolumn{4}{|c|}{ Belirgin Dalga Yüksekliği (m) } \\
\hline \multirow[t]{5}{*}{$(\mathrm{TO}=0,05)$} & $2,5-2,0$ & 0,503 & 1,000 \\
\hline & $2,0-1,5$ & 0,260 & 0,517 \\
\hline & $1,5-1,0$ & 0,134 & 0,266 \\
\hline & $1,0-0,75$ & 0,068 & 0,135 \\
\hline & $0,5-0,75$ & 0,035 & 0,070 \\
\hline \multicolumn{4}{|c|}{ Deniz Derinliği (m) } \\
\hline \multirow[t]{5}{*}{$(\mathrm{TO}=0,02)$} & $0-10$ & 0,416 & 1,000 \\
\hline & $10-20$ & 0,262 & 0,630 \\
\hline & $20-30$ & 0,161 & 0,387 \\
\hline & $30-40$ & 0,099 & 0,238 \\
\hline & $40-50$ & 0,062 & 0,149 \\
\hline \multicolumn{4}{|c|}{$\begin{array}{l}\text { Trafo Merkezlerine Uzaklık (km) } \\
(\mathrm{TO}=0,03)\end{array}$} \\
\hline & $1-10$ & 0,327 & 1,000 \\
\hline & $10-20$ & 0,227 & 0,694 \\
\hline & $20-30$ & 0,157 & 0,480 \\
\hline & $30-40$ & 0,108 & 0,330 \\
\hline & $40-50$ & 0,073 & 0,223 \\
\hline & $50-60$ & 0,050 & 0,153 \\
\hline & $60-70$ & 0,034 & 0,104 \\
\hline & $>70$ & 0,024 & 0,073 \\
\hline \multicolumn{4}{|c|}{ Limanlara Uzaklık (km) } \\
\hline & $0-20$ & 0,503 & 1,000 \\
\hline & $20-40$ & 0,260 & 0,517 \\
\hline & $40-60$ & 0,134 & 0,266 \\
\hline & $60-80$ & 0,068 & 0,135 \\
\hline & $>80$ & 0,035 & 0,070 \\
\hline \multicolumn{4}{|c|}{ Kıyıya Uzaklık (km) } \\
\hline \multirow[t]{5}{*}{$(\mathrm{TO}=0,02)$} & $5-15$ & 0,416 & 1,000 \\
\hline & $15-25$ & 0,262 & 0,630 \\
\hline & $25-35$ & 0,161 & 0,387 \\
\hline & $35-45$ & 0,099 & 0,238 \\
\hline & $>45$ & 0,062 & 0,149 \\
\hline \multicolumn{4}{|c|}{ Deniz Tabanı Çökel Tipleri } \\
\hline & Kum & 0,380 & 1,000 \\
\hline & Çamurlu kum & 0,249 & 0,655 \\
\hline & Kumlu çamur & 0,160 & 0,421 \\
\hline & Çamur & 0,102 & 0,268 \\
\hline & Karışık çökel & 0,066 & 0,174 \\
\hline & Kaba çökel & 0,043 & 0,113 \\
\hline
\end{tabular}


Hesaplanan değerlere göre CBS ortamında normalleştirilmiş kriter katmanları oluşturulmuştur (Şekil 3).

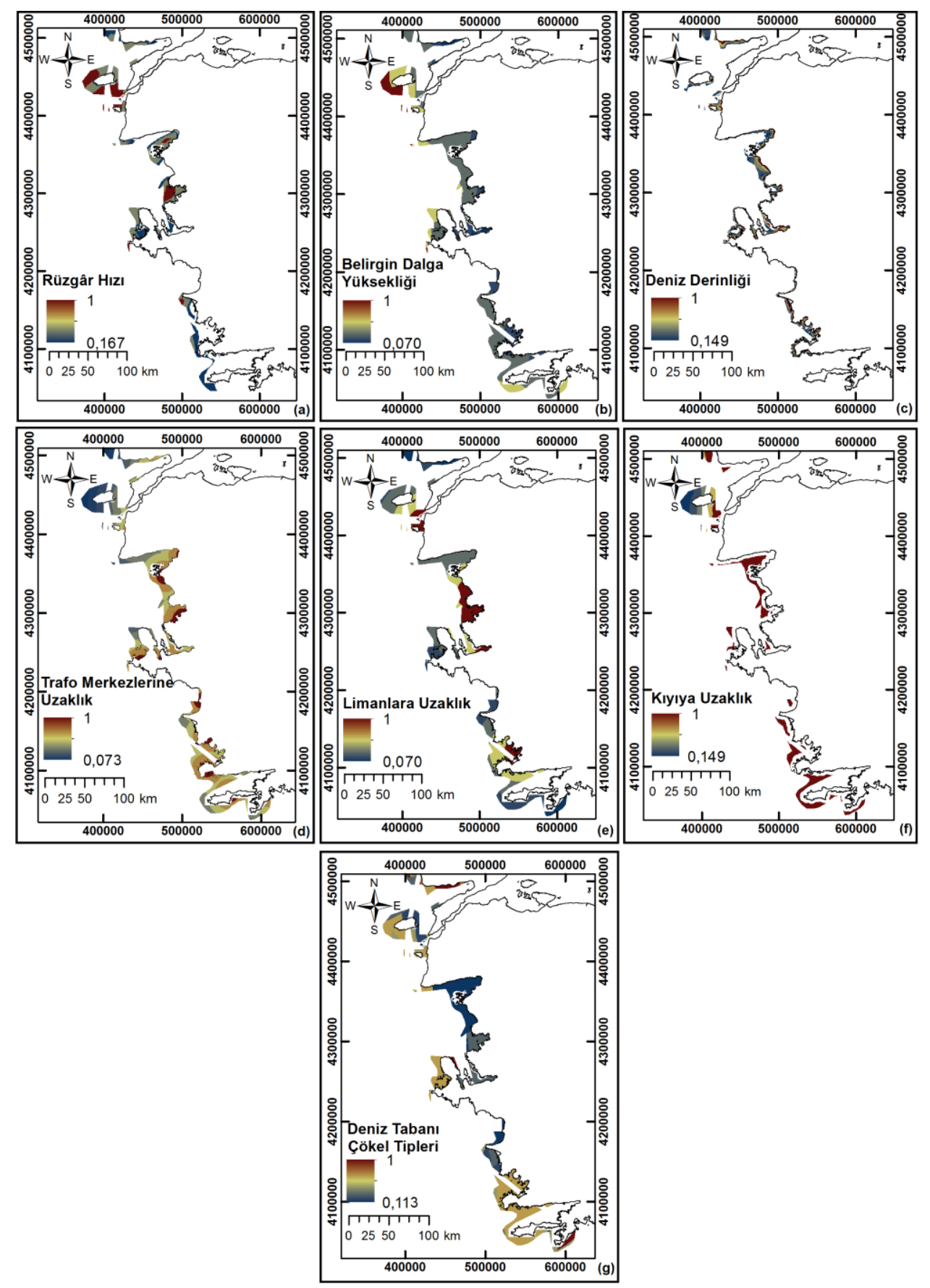

Şekil 3. Normalleştirilmiş kriter katmanları (a) Rüzgâr hızı, (b) Belirgin dalga yüksekliği, (c) Deniz derinliği, (d) Trafo merkezlerine uzaklık, (e) Limanlara uzaklık, (f) Kıyıya uzaklık, (g) Deniz tabanı çökel tipleri 
DEÜ FMD 23(67), 217-232, 2021

\subsection{Analitik Hiyerarşi Yöntemi ile uygunluk haritasının oluşturulması}

Ege Denizi'nde rüzgâr ve dalga enerji sistemleri için yer seçimi probleminde, son adım olarak normalleștirilmiş katmanlar ve kriter ağırlıkları Eşitlik (1)'de işleme konularak CBS ve AHY'ye dayalı uygunluk haritası oluşturulmuştur. Analiz sonuçları ve sonuçların sınıflandırılması Bulgular ve Tartışma bölümünde ayrıntılı olarak ele alınmaktadır.

\section{Bulgular ve Tartışma}

Ege Denizi'nde rüzgâr ve dalga enerji sistemleri için uygun alanların belirlenmesi amacıyla gerçekleștirilen CBS tabanlı AHY analiz sonucu Şekil 4'te gösterilmektedir. Analiz sonucuna göre değerler 0,22-0,93 aralığında yer almaktadır. Yüksek değerlerler rüzgâr ve dalga enerji sistemlerinin kurulumu için daha uygun alanları temsil etmektedir.

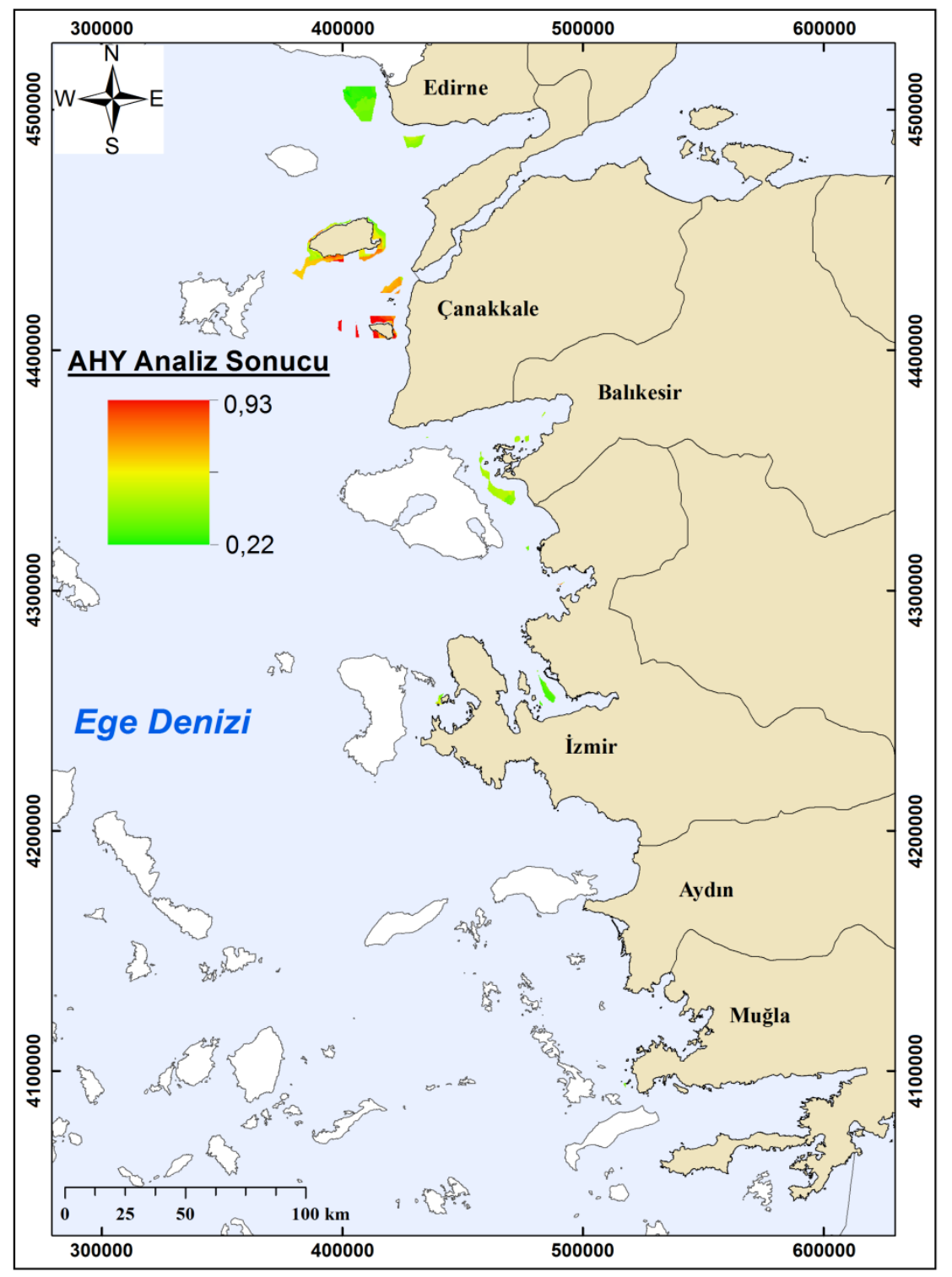

Şekil 4. CBS tabanlı AHY analiz sonucu 
AHY ile elde edilen analiz sonuçlarının daha kolay yorumlanabilmesi amaciyla CBS ortamında "eşit aralıklı sınıflandırma" kullanılarak analiz sonuçları "1: Cok Yüksek Uygunlukta Alanlar", "2: Yüksek Uygunlukta
Alanlar", 3: Orta Uygunlukta Alanlar", "4: Düşük Uygunlukta Alanlar" ve "5: Çok Düşük Uygunlukta Alanlar" olmak üzere beş sınıfa ayrılmıștır (Şekil 5a).

\section{EGE DENİİ RÜZGÂR VE DALGA ENERJI SISTEMLERİ İÇIN UYGUNLUK HARİTASI}

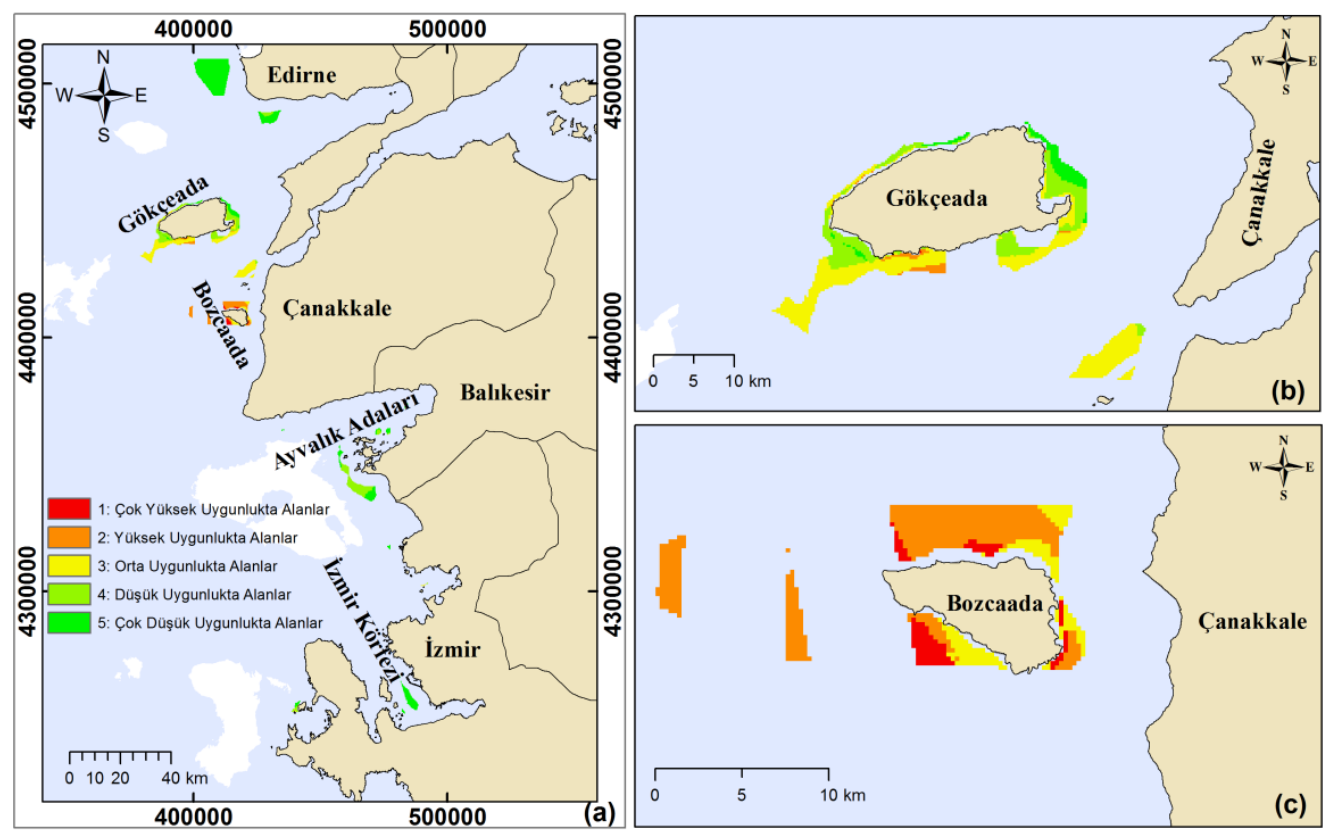

Şekil 5. Ege Denizi rüzgâr ve dalga enerji sistemleri kurulumu için kategorik uygunluk haritası

Yapılan sınıflandırma sonucu "1: Çok Yüksek Uygunlukta Alanlar" ve "2: Yüksek Uygunlukta Alanlar" olarak ilk iki kategorideki alanlar, rüzgâr ve dalga enerji sistemlerinin yerleştirilebileceği uygun alanlar olarak değerlendirilmiştir. Analiz sonucunda Ege Denizi'nde rüzgâr ve dalga enerji sistemleri için uygun alanların Bozcada ve Gökçeada çevresinde yer aldığı belirlenmiş olup özellikle Bozcada çevresinde daha fazla yoğunlaștığ görülmektedir (Şekil 5b ve 5c). Tablo 8'de Ege Denizinde rüzgâr ve dalga enerji sistemlerinin yerleștirilebileceği uygun alanların ("1: Çok Yüksek Uygunlukta Alanlar" ve "2: Yüksek Uygunlukta Alanlar") yüzölçümü değerleri verilmektedir. Tablo 8'e göre Bozcaada ve Gökçeada çevresinde $50,4 \mathrm{~km}^{2}$ alanın entegre rüzgâr ve dalga enerji sistemlerinin kurulabileceği uygun alanlar olduğu ve bu değerin 43,4 $\mathrm{km}^{2}$ sinin Bozcaada çevresinde bulunduğu belirlenmiştir. 50,4 $\mathrm{km}^{2}$ alanın 7,2 $\mathrm{km}^{2}$ 'si "1: Çok Yüksek Uygunlukta Alanlar" ve $43,2 \mathrm{~km}^{2}$ 'si "2: Yüksek Uygunlukta Alanlar" olarak sınıflandırılmış alanlardır.

$\mathrm{Bu}$ çalıșmada; rüzgâr hızı ve belirgin dalga yüksekliği, entegre rüzgâr ve dalga enerji sistemleri için en önemli kriterlerdir. Fakat sistemlerin kurulum yeri belirlenirken en yüksek potansiyele sahip alanlar kurulum alanı olarak doğrudan değerlendirilmemelidir. $\mathrm{Bu}$ çalışmanın sonuçlarında görüldüğü gibi yüksek rüzgâr hızına ve belirgin dalga yüksekliğine sahip alanlardan biri olan Gökçeada çevresi, diğer faktörler dikkate alınmadan değerlendirildiğinde çok uygun alan olarak düşünülebilirken diğer faktörlerin değerlendirmeye alınmasıyla uygun alanların Bozcaada çevresine göre çok daha az olduğu görülmektedir (Şekil 5 ve Tablo 8). 
DEÜ FMD 23(67), 217-232, 2021

Tablo 8. Ege Denizinde rüzgâr ve dalga enerji sistemlerinin yerleștirilebileceği uygun alanların yüzölçümü

\begin{tabular}{lccc}
\hline Bölge & $\begin{array}{c}\text { 1: Çok Yüksek Uygunlukta } \\
\text { Alanlar }\left(\mathbf{k m}^{\mathbf{2}}\right)\end{array}$ & $\begin{array}{c}\text { 2: Yüksek Uygunlukta } \\
\text { Alanlar }\left(\mathbf{k m}^{2}\right)\end{array}$ & $\begin{array}{c}\text { Toplam Alan } \\
\left(\mathbf{k m}^{\mathbf{2}}\right)\end{array}$ \\
\hline Bozcaada çevresi & 7,1 & 36,3 & 43,4 \\
Gökçeada çevresi & 0,1 & 6,9 & 7,0 \\
\hline Toplam & $\mathbf{7 , 2}$ & $\mathbf{4 3 , 2}$ & $\mathbf{5 0 , 4}$ \\
\hline
\end{tabular}

Sonuçlar üzerinde etkili bir diğer önemli faktör deniz derinliğidir. Ege Denizi karasularının genelini 50 m'den derin alanlar olușturmaktadır. Teknolojik ve mali kısıtlamalar nedeniyle $50 \mathrm{~m}$ derinliğinden fazla olan alanlar analize dâhil edilmemiştir. $\mathrm{Bu}$ nedenle ilerleyen zamanlarda bu alanların değerlendirmeye alınmasının mümkün olması durumunda Ege Denizi'nde daha fazla alan kurulabilir alan olarak değerlendirilebilecektir.

Çalışmada seçilen limanlar kurulum için büyük rüzgâr türbinlerini taşıyabilecek kapasitede olan limanlar olarak seçilmiştir. Ancak balıkçı limanları gibi farklı amaçla kullanılan daha küçük çaplı limanlar da uygun bir konumda ise kamu yararı görülüp denetimi yapılması ve ișletme izni alınması koșulu ile limana ek bir platform yapılıp kullanılabilir ya da enerji sistemleri için özel olarak yeni limanlar inşa edilebilir.

Kıyıya olan mesafe faktörü, ülkelerin kullanım haklarına sahip oldukları deniz genișliklerine göre arttırılabilir. Özellikle açık denizlerde çok daha fazla enerji potansiyeli bulunmaktadır. Bu nedenle enerji sistemlerinin açlk denizlere kurulması ile enerji üretiminde artıș sağlanabilmektedir. Fakat kıyıdan uzaklaștıkça artan avantajların yanında maliyetlerde de artış görülmektedir. $\mathrm{Bu}$ nedenle kıyıdan belirli bir mesafe sonrası maliyeti arttırması açısından değerlendirilmeye alınmayabilir. Bununla birlikte, rüzgâr türbinlerinin kıyıdan görülmesinin istenmediği ve kıyıdan itibaren belirli bir mesafenin değerlendirmeye alınmadığı durumlar da olabilmektedir. Ancak kıyı mesafesinden görülen türbin görüntüsünün olumsuz etki olușturmadığı ve turizme olumlu katkısı olduğu yönünde görüşler de mevcuttur. $\mathrm{Bu}$ nedenle çalışma alanının durumuna ve şartlarına bağlı olarak enerji üretimindeki artış, maliyet ve görsel etki faktörleri birlikte değerlendirilerek kıyıdan uzaklık kriteri farklı şekillerde ele alınabilir.
Ayrıca fay hatları ve boru hatları gibi tehlike olușturabilecek durumların daha önceden bilinmesi ve değerlendirmeye dâhil edilmesi; olası bir proje iptalinin önüne geçilmesi, ekonomik kayıpların yaşanmaması ve daha sonra oluşabilecek bir kazanın önlenmesi açısından oldukça önemlidir. $\mathrm{Bu}$ nedenle çalışma alanını çok yönlü değerlendirmek gerekmektedir. Ancak bu çalışma kapsamında, ülkemizde özellikle denizler ile ilgili verilerin eksikliği görülmüştür. Tüm yönleri ile ele alınması gereken bir problemde veri temininde yaşanan zorluk, değerlendirmenin sonuçları üzerinde etkili olabilecek en büyük engellerden biridir.

$\mathrm{Bu}$ çalışmada; rüzgâr ve dalga enerji sistemlerinin yer seçimi, tesis sınıfı (ortak alana yerleştirilmiş sistemler, hibrit sistemler ve ada sistemleri), tesiste kullanılacak cihaz türleri ve temel tipinden bağımsız olarak gerçekleştirilmiştir. Tesis sınıfı, cihaz türleri ve temel tipinin belirlenmesi durumunda kriter değerlendirmeleri daha spesifik olarak ele alınabilir.

Çalışmanın bulguları, CBS tabanlı AHY'nin denizlerde rüzgâr ve dalga enerji sistemleri için yer seçimi problemlerinde etkin bir șekilde kullanılabileceğini göstermiştir. Ancak kriterlerin ve ağırlıkların belirlenmesi, ÇKKA'nin doğası gereği öznellik barındırır ve bu öznellikleri tamamen ortadan kaldırmak imkansızdır. Bununla birlikte, bu öznelliği azaltmak için bazı yaklaşımlar kullanılabilir. Uzman görüşlerine dayalı grup karar verme veya çoklu literatüre dayalı değerlendirme bu kapsamda en temel ve basit yaklașımdır. Bu çalışmada, konunun yeni olmasından dolayı ülkemizde yeteri kadar birikim ve tecrübe henüz oluşmadığından uzman görüșlerine dayalı grup karar verme gerçekleştirilememiş, hem kriterlerin belirlenmesinde hem de ağırlıklandırılmasında konu ile ilgili literatür dikkate alınmıştır. Kriterlerin ve alt 
kategorilerin/gruplandırılmıș seçeneklerin ağırlıkları, AHY'ye göre ikili karşılaştırma yöntemi ile belirlenmiştir. Potansiyel yanlılığı azaltmak için, ikili karşılaștırmaların tutarlılık oranı hesaplanmış ve tutarlılık oranlarının Saaty (1980) tarafından önerilen 0,10 eşik değerinin altında olduğu kontrol edilmiştir.

\section{Sonuç ve Öneriler}

Nüfus artışı ve teknolojik gelişmelere paralel olarak enerji tüketiminin artması, fosil yakıt kullanımının hâkim olduğu bu dönemde, çevrenin geri dönülemez bir şekilde zarar görmesi başta olmak üzere birçok probleme sebep olmaktadır. Bu nedenle, uygun alanlara konumlandırıldığı sürece çevre üzerinde zararı bulunmayan, ilk yatırım maliyeti ve bakım giderlerinden başka bir maliyeti olmayan, enerji alanında dışa bağımı ı̆̆ının azaltıldığı ve sürekli olarak doğada var olan yenilenebilir enerji kaynaklarının kullanımı giderek artmaktadır. Ülkemiz konumu gereği yenilenebilir enerji kaynakları yönünden oldukça avantajlıdır. Karada kurulabilecek enerji sistemlerinin yanında, üç tarafı denizlerle çevrili olan ülkemiz, deniz enerji sistemleri kurulumu için de değerlendirilmelidir.

Kara üzerinde kurulu rüzgâr santrallerinin kurulabileceği alanların giderek kısıtlanması, türbinlerin çıkardıkları gürültünün olumsuz etkileri ve deniz üzerindeki rüzgârların karaya oranla daha güçlü olması gibi nedenler sonucu denizlerde rüzgâr türbini kurulumu dünyada yaygınlașmaya bașlamıștır. Denizlerde rüzgâr santrallerinin tek başına değil, dalga enerji sistemleri ile entegre bir șekilde kullanılmasının oldukça avantajlı olacağı düşünülmektedir. Yeni bir araştırma konusu olan entegre rüzgâr ve dalga enerji sistemleri ile üretilen enerji miktarında artış sağlanabilecek, sistemlerin birbirlerinden uzak farklı noktalara kurulması durumundaki alan kaybı giderilebilecek ve kurulum ve bakım maliyetleri azaltılabilecektir.

Bu değerlendirmeler ışığında karasularının çok dar olduğu Ege Denizi için entegre rüzgâr ve dalga enerji sistemleri en uygun enerji sistemlerinden biri olmaktadır. $\mathrm{Bu}$ çalışma kapsamında CBS tabanlı AHY yöntemi ile Ege Denizi'nde entegre rüzgâr ve dalga enerji sistemleri için yer seçimi amacıyla uygunluk haritası hazırlanmıș, "1: Çok Yüksek Uygunlukta Alanlar", "2: Yüksek Uygunlukta Alanlar" olarak sınıflandırılan alanlar hem enerji potansiyeli hem de yer seçiminde etkili diğer faktörler açısından kurulum yapılabilecek uygun alanlar olarak görülmüş ve bu alanların genel olarak Bozcaada çevresinde dağıldığı tespit edilmiştir. $\mathrm{Bu}$ çalışmada Ege Denizi üzerinde genel bir değerlendirme yapılmış olup analiz sonuçlarına göre belirlenen uygun alanlarda daha ayrıntı bir çalışma yapılarak tesis yeri lokalize olarak belirlenebilir.

Çalışmanın sonucunda, CBS tabanlı AHY ile entegre rüzgâr ve dalga enerji sistemleri için uygunluk haritasının oluşturulmasıyla enerji kaynaklarından en verimli ve ekonomik şekilde yararlanılabileceği öngörülmektedir. Ayrıca iklim koşulları ve deniz alanlarının kullanımı değişim gösterebileceğinden ve yasal düzenlemeler ya da teknolojik gelişmeler sonucu kriterlerin ve kısıtlamaların değișmesi söz konusu olabileceğinden CBS tabanlı AHY ile değișen koșullara göre haritanın revizyonu kısa sürede ve etkin bir șekilde mümkün olabilecektir.

Çalıșmada entegre rüzgâr ve dalga enerji sistemleri için uygun yer seçimi problemi Ege Denizi için ele alınmış olmakla birlikte, önerilen metodoloji kullanılarak daha geniș karasularına sahip Karadeniz ve Akdeniz üzerinde de rüzgâr ve dalga enerji sistemleri için uygun alanlar tespit edilebilir. Rüzgâr ve dalga enerji sistemleri için yer belirleme problemlerinde gerekli olan verilerin eksiksiz temin edilebilmesi, tüm etken faktörlerin ele alınabilmesi açısından önemli bir konu olup gerekli verilerin ilgili kurum ve kuruluşlarca hazırlanması ve paylaşımı sağlanmalıdır. Bununla birlikte rüzgâr ve dalga enerji sistemleri kurulumuna uygun olmayan alanlar açıcça belirtilmeli ve bu konu ile ilgili gerekli yasal düzenlemeler yapılmalıdır.

\section{Kaynakça}

[1] Nelson, V.C. 2011. Introduction to Renewable Energy. CRC Press, Boca Raton, 384s.

[2] Smith, Z.A., Taylor, K.D. 2008. Renewable and Alternative Energy Resources: A Reference Handbook. ABC-CLIO, Santa Barbara, California, 323s.

[3] Tong, W. 2010. Wind Power Generation and Wind Turbine Design. WIT Press, Southampton, Boston, 768s.

[4] Breeze, P. 2016. Wind Power Generation. Academic Press, London, 104s.

[5] Neill, S.P., Hashemi, M.R. 2018. Fundamentals of Ocean Renewable Energy: Generating Electricity From the Sea. Academic Press, 336s. 
[6] Gasch, R., Twele, J. 2011. Wind Power Plants: Fundamentals, Design Construction and Operation. Springer Science \& Business Media, Heidelberg, 566s.

[7] Pérez-Collazo, C., Astariz, S., Adanades, J., Greaves, D., Iglesias, G. 2014. Co-Located Wave and Offshore Wind Farms: A Preliminary Case Study of an Hybrid Array. International Conference in Coastal Engineering (ICCE), 15-20 June, Seul, South Korea.

[8] Moschos, E., Manou, G., Dimitriadis, P., Afentoulis, V., Koutsoyiannis, D., Tsoukala, V.K. 2017. Harnessing Wind and Wave Resources for a Hybrid Renewable Energy System in Remote Islands: A Combined Stochastic and Deterministic Approach, Energy Procedia, Cilt 125, s. 415-424. DOI: 10.1016/j.egypro.2017.08.084

[9] Pérez-Collazo, C., Greaves, D., Iglesias, G. 2015. A Review of Combined Wave and Offshore Wind Energy, Renewable and Sustainable Energy Reviews, Cilt 42, s. 141-153. DOI: 10.1016/j.rser.2014.09.032

[10] Pérez-Collazo, C., Jakobsen, M.M., Chozas, J.F., Buckland, H. 2013. Synergies for a Wave-wind Energy Concept. European Offshore Wind Energy Conference-EWEA OFFSHORE, 19-21 November, Frankfurt, Germany.

[11] Pérez, C., Iglesias G. 2012. Integration of Wave Energy Converters and Offshore Windmills. 4th International Conference on Ocean Energy, 17-19 October, Dublin, Ireland.

[12] Derakhshan, S., Moghimi, M., Motawej, H. 2018. Development of a Mathematical Model to Design an Offshore Wind and Wave Hybrid Energy System, Energy Equipment and Systems, Cilt 6 (2), s. 181200.

[13] Brooke, J. 2003. Wave Energy Conversion. Elsevier, Amsterdam, 204s.

[14] Multon, B. 2013. Marine Renewable Energy Handbook. John Wiley \& Sons, Hoboken, 643s.

[15] Linkov, I., Moberg, E. 2011. Multi-criteria Decision Analysis: Environmental Applications and Case Studies. CRC Press, Boca Raton, 204 s.

[16] Saaty, T.L. 2012. Decision Making for Leaders: The Analytic Hierarchy Process for Decisions in a Complex World. RWS Publications, Pittsburgh, 323s.

[17] Schmoldt, D.L., Kangas, J., Mendoza, G.A., Pesonen M. 2013. The Analytic Hierarchy Process in Natural Resource and Environmental Decision Making, Cilt 3. Springer Science \& Business Media, Dordrecht, $307 \mathrm{~s}$.

[18] Cristóbal, J.R.S. 2012. Multi-criteria Analysis in the Renewable Energy Industry. Springer-Verlag, London, 116s.

[19] Matejicek, L. 2017. Assessment of Energy Sources Using GIS. Cham, Springer International Publishing AG, Switzerland, 344s.

[20] Malczewski, J. 1999. GIS and Multicriteria Decision Analysis. John Wiley \& Sons, New York, 408s.

[21] DPT 2001. Sekizinci Beş Yıllık Kalkınma Planı, Elektrik Enerjisi Özel İhtisas Komisyonu Raporu, Ankara. http://www.sbb.gov.tr/wpcontent/uploads/2018/11/08_ElektrikEnerjisi.pdf (Erişim Tarihi: 17.08.2019)

[22] Yerci, V. 2015. Türkiye Denizlerindeki Rüzgâr Enerjisi Potansiyeli ve Deniz Üstü Rüzgâr Santralleri
Kurulabilecek Bölgelerin Belirlenmesi. Yüksek Lisans Tezi, Mevlana Üniversitesi Fen Bilimleri Enstitüsü Elektrik-Elektronik Mühendisliği Anabilim Dalı, 68s, Konya.

[23] Bașeren, S.H. 2006. Ege Sorunları. Tüdav Yayınları, Ankara, 260s.

[24] Tokac, A., Ünal, V., Tosunoğlu, Z., Akyol, O., Özbilgin, H., Gökçe, G. 2010. Ege Denizi Balıkçılığı. IMEAK Deniz Ticaret Odası İzmir Şubesi Yayınları, İzmir, 390s.

[25] Köksal, A. 1998. Ege Bölgesinin Turizm Coğrafyası, Ankara Üniversitesi Dil ve Tarih-Coğrafya Fakültesi Dergisi, Cilt 32 (1-2), s. 57-61.

[26] Ulaştırma Bakanlığı 2010. Turizm Kıyı Yapıları Master Plan Çalışması Sonuç Raporu. Yüksel Proje Uluslararası A.Ş. ve Belde Proje ve Danışmanlık Tic. Ltd. Şti., Ankara.

[27] Mansel, A.M. 1999. Ege ve Yunan Tarihi. Türk Tarih Kurumu Basımevi, Ankara, 707s.

[28] Dışişleri Bakanlığı 2011. Başlıca Ege Denizi Sorunlarl. http://www.mfa.gov.tr/baslica-egedenizi-sorunlari.tr.mfa (Erișim Tarihi: 19.11.2018)

[29] Saaty, T.L. 1986. Axiomatic Foundation of the Analytic Hierarchy Process, Management Science, Cilt 32 (7), s. 841-855.

[30] Öztürk D., Batuk F. 2010. Konumsal Karar Problemlerinde Analitik Hiyerarşi Yönteminin Kullanılması, Sigma Mühendislik ve Fen Bilimleri Dergisi, Cilt 28, s. 124-137.

[31] Nobre, A., Pacheco, M., Jorge, R., Lopes, M.F.P., Gato, L.M.C. 2009. Geo-spatial Multi-criteria Analysis for Wave Energy Conversion System Deployment, Renewable Energy, Cilt 4, s. 97-111. DOI: 10.1016/j.renene.2008.03.002

[32] Boelen, M.A., Bishop, I., Pettit, C. 2011. Selecting Offshore Renewable Energy Futures for Victoria, The International Archives of the Photogrammetry, Remote Sensing and Spatial Information Sciences, Cilt 38, s. 478-483.

[33] Vagiona, D.G., Karanikolas, N.M. 2012. A Multicriteria Approach to Evaluate Offshore Wind Farms Siting in Greece. Global NEST Journal, Cilt 14 (2), s. 235-243.

[34] Verfaillie, E., De Wulf, A., Goethals, M., Gysens, S., Meire, E., De Maeyer, P. 2012. Suitability Mapping for Renewable Energy Potential in the North Sea Results from the BLAST Project. Conference Proceedings of Hydro12, 12-15 November, 319-323, Rotterdam, Netherlands.

[35] Maulud, K.N.A., Mohtar, W.H.M.W., Karim, O.A. 2013. Spatial Multi Criteria Analysis for the Determination of Areas with High Potential Wave Energy, Jurnal Teknologi (Sciences \& Engineering), Cilt 65 (2), 113-120.

[36] Le, P., Fischer, A., Penesis, I., Rahimi, R. 2016. Aggregating GIS and MCDM to Optimize Wave Energy Converters Location in Tasmania, Australia. ss. 943-966. Information Resources Management Association, ed. Geospatial Research: Concepts, Methodologies, Tools, and Applications, IGI Global, Hershey, 1997s.

[37] Flocard, F., Ierodiaconou., D., Coghlan, I.R. 2016. Multi-criteria Evaluation of Wave Energy Projects on the South-east Australian Coast, Renewable 
DEÜ FMD 23(67), 217-232, 2021

Energy, Cilt 99, s. 80-94. DOI: 10.1016/j.renene.2016.06.036

[38] Martinez, A., Mustapha, Z.B., Campbell, R. 2016. An Aid Decision Tool for Implementing Wave Energy Devices on the Coast, International Journal of Sustainable Energy Development, Cilt. 5 (1), s. 233242.

[39] Chaouachi, A., Covrig, C.F., Ardelean, M. 2017. Multicriteria Selection of Offshore Wind Farms: Case Study for the Baltic States, Energy Policy, Cilt 103, s. 179-192. DOI: 10.1016/j.enpol.2017.01.018

[40] Vasileiou, M., Loukogeorgaki, E., Vagiona, D.G. 2017. GIS-based Multi-criteria Decision Analysis for Site Selection of Hybrid Offshore Wind and Wave Energy Systems in Greece, Renewable and Sustainable Energy Reviews, Cilt 73, s. 745-757. DOI: 10.1016/j.rser.2017.01.161

[41] Mahdy, M., Bahaj, A.S. 2018. Multi Criteria Decision Analysis for Offshore Wind Energy Potential in Egypt, Renewable Energy, Cilt 118, s. 278-289. DOI: 10.1016/j.renene.2017.11.021

[42] Gavériaux, L., Laverrière, G., Wang, T., Maslov, N., Claramunt, C. 2019. GIS-based Multi-criteria Analysis for Offshore Wind Turbine Deployment in Hong Kong, Annals of GIS, Cilt 25 (3), s. 207-218.

[43] YEGM 2018. REPA-Alansal Rüzgâr Kaynak Bilgisi Temini için Yapılması Gerekenler ve Örnek Raporu. http://www.yegm.gov.tr/yenilenebilir/document/ Guncel_REPA_Alansal.doc (Erişim tarihi: 01.04.2018)

[44] Cevre ve Sehircilik Bakanlığı 2017. CED Alanında Kapasitesinin Güçlendirilmesi için Teknik Yardım Projesi: Rüzgâr Enerji Santralleri. http://webdosya.csb.gov.tr/db/ced/icerikler/ruzga r-enerji-santralleri-20180418123831.docx (Erișim Tarihi: 09.08.2018)

[45] Schlütter, F., Petersen, O.S., Nyborg, L. 2015. Resource Mapping of Wave Energy Production in
Europe. 11th European Wave and Tidal Energy Conference, 6-11 September, Nantes, France.

[46] Vagiona, D.G., Kamilakis, M. 2018. Sustainable Site Selection for Offshore Wind Farms in the South Aegean-Greece, Sustainability, Cilt 10 (3), s. 1-18. DOI: $10.3390 /$ su10030749

[47] Murphy, J., Lynch, K., Serri, L., Airdoldi, D., Lopes, M. 2011. ORECCA Site Selection Analysis For Offshore Combined Resource Projects in Europe. Results of the FP7 ORECCA Project Work Package 2, Hydraulic and Maritime Research Centre (HMRC), Cork, Ireland.

[48] Sandberg, A.B., Klementsen, E., Muller, G., De Andres, A., Maillet, J. 2016. Critical Factors Influencing Viability of Wave Energy Converters in Off-grid Luxury Resorts and Small Utilities, Sustainability, Cilt 8, s. 1-22. DOI: $10.3390 /$ su8121274

[49] Weiss, C.V.C. Guanche, R., Ondiviela, B., Castellanos, O.F., Juanes, J. 2018. Marine Renewable Energy Potential: A Global Perspective for Offshore Wind and Wave Exploitation, Energy Conversion and Management, Cilt 177, s. 43-54. DOI: 10.1016/j.enconman.2018.09.059

[50] Coughlan, M., Wheeler, A., Dorschel, B. 2015. Offshore Renewable Energy Site Suitability Mapping (ORESSuM). University College Cork, Ireland, doi: 10.13140/RG.2.1.3988.5284

[51] Saaty, T.L., Kearns, K.P. 2014. Analytical Planning: The Organization of System. Elsevier, Amsterdam, $216 s$.

[52] Yoon, K.P., Hwang, C-L. 1995. Multiple Attribute Decision Making: An Introduction. SAGE Publications, Thousand Oaks, 84s. 